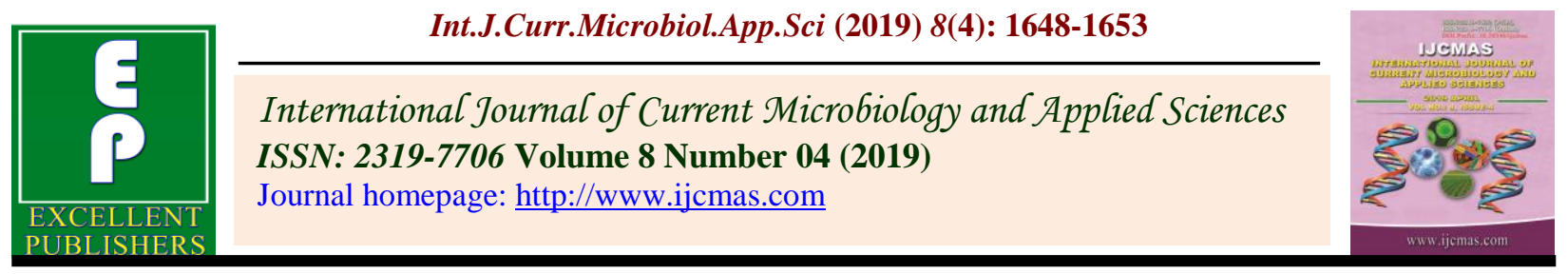

Original Research Article

https://doi.org/10.20546/ijcmas.2019.804.192

\title{
Effect of Weather Parameters on Population Dynamics of Mustard Aphid
}

\author{
Sevak Das $^{1 *}$, D.N. Tejani ${ }^{2}$, J.C. Patel $^{1}$, A.G. Desai ${ }^{2}$, A. I. Desai ${ }^{1}$ and G.P. Gangwar ${ }^{2}$ \\ ${ }^{1}$ Department of Agricultural Meteorology, C. P. College of Agriculture \\ ${ }^{2}$ Castor-Mustard Research Station, S. D. Agricultural University, \\ Sardarkrushinagar- 385 506, India \\ *Corresponding author
}

\begin{tabular}{|c|c|}
\hline & A B S T R A C T \\
\hline & \multirow{6}{*}{$\begin{array}{l}\text { To assess the impact of weather parameters on mustard aphid, a field experiment was } \\
\text { conducted during Rabi season } 2011-12 \text { to } 2017-18 \text { at Main Castor-Mustard Research } \\
\text { Station, S.D. Agricultural University, Sardarkrushinagar. The experiment was laid down in } \\
\text { randomized block design consisting five varietal treatments viz. BSH-1, GSC- } 6 \text {, T-27, GS- } \\
1 \text { and GDM- } 4 \text { with three replications. The crop was sown during } 24^{\text {th }}-30^{\text {th }} \text { Sept as timely } \\
\text { sown crop and } 15^{\text {th }}-21^{\text {st }} \text { Oct as late sown crop. The results revealed that the maximum } \\
\text { incidence of aphid was observed in late sown crop as compared to early sown crop. The } \\
\text { correlation study between aphid population and weather parameters revealed that the } \\
\text { maximum temperature (Tmax), minimum temperature (Tmin) and growing degree days } \\
\text { (GDD) had significant negative correlation with aphid population. Morning relative } \\
\text { humidity, evening relative humidity, sunshine hours and wind speed did not have } \\
\text { significant correlation with aphid population. The regression models were developed with } \\
\text { Tmax and GDD could explain } 72 \text { to } 87 \text { percent variation in aphid population in different } \\
\text { cultivars. }\end{array}$} \\
\hline & \\
\hline $\begin{array}{l}\text { Aphid, Mustard } \\
\text { and weather }\end{array}$ & \\
\hline Article Info & \\
\hline $\begin{array}{l}\text { Accepted: } \\
\text { 12 March } 2019 \\
\text { Available Online: } \\
10 \text { April } 2019\end{array}$ & \\
\hline & \\
\hline
\end{tabular}

\section{Introduction}

Rapeseed mustard (Brassica Spp.) is the second most important oil seed crop of the country after groundnut which contributes about $25-30 \%$ of total oil seeds production. In India, it is mainly cultivated in Rajasthan, Uttar Pradesh, Madhya Pradesh, Bihar, Assam, Gujarat, Maharashtra, Haryana and West Bengal in various agro-ecological situations. Mustard is a cool season crop and cultivated in the tropical as well as in the temperate climates. In spite of fact, Indian mustard plays an important role in agriculture economy due to growing under diverse conditions. However, the mustard average yields in our country yet low as compared to other countries due to many constraints like delay sowing, pest diseases incidence and others management practices. Among different insect pest of mustard, aphid infestation is one of the major problems and widely distributed throughout the world. It causes damage directly by sucking the phloem from the different parts of the plants (Ali and Rizvi, 2007). The population dynamics of this pest considered to be highly influenced by prevailing weather condition particularly temperature and relative humidity. Several studies have been indicated 
that weather plays an important role on the aphid appearance, multiplication and disappearance (Srivastava and Srivastava, 1972; Roy, 1975; Jitendra Kumar et al., 1999; Srivastava, 1999; Vekaria and Patel, 2000). The efforts have been made by Prasad and Phadke (1984); Rana et al., (1993) to correlate the temperature and relative humidity with the incidence and multiplication of aphid in the mustard crop. The changes in aphid population with change in weather parameters enable to forecast the population of mustard aphid under changing scenarios of climate using statistical approaches.

The study would be helpful to challenge the pest by manipulating the manageable ecological parameters like planting or harvesting time adjustment, varietals selection, timely application of insecticides etc. Statistical forewarning models is the best approach that would be helpful to provide the information regarding incidence of pest in an advance based on medium range weather forecast and such information would be incorporate in Agromet advisory bulletins of the GKMS project. Thus, an attempt has been made to quantify the relationship between weather parameters and appearance, development of aphids in mustard crop at Sardarkrushinagar.

\section{Materials and Methods}

A field experiment was conducted on mustard crop during Rabi season 2011-12 to 2017-18 at Main Castor-Mustard Research Station, Sardarkrushinagar Dantiwada Agricultural University, Sardarkrushinagar to find out the impact of weather on population dynamic of mustard aphid. Geographically, the location is situated at $24.19^{\circ} \mathrm{N}$ latitude and $72.19^{\circ} \mathrm{E}$ longitude at an altitude of $154.5 \mathrm{~m}$ above mean sea level having arid to semi-arid climate. The experiment was laid down in randomized block design consisting five varietal treatments viz. BSH-1, GSC-6, T-27, GS-1 and GDM-4 with three replications. The crop was sown during $24^{\text {th }}-30^{\text {th }}$ Sept as timely sown crop and $15^{\text {th }}-21^{\text {st }}$ Oct as late sown crop. The plots were maintained following the recommended agronomic practices in same manner for all the treatments. The all plots were kept free from any insecticidal spray throughout the crop period. The number of aphids per $10 \mathrm{~cm}$ of the main shoot of the 10 pre-labeled randomly selected plants from each plot was counted at weekly interval from the day of aphid appearance in the field and then was averaged.

The daily meteorological parameters like maximum temperature (Tmax), minimum temperature (Tmin), morning relative humidity (RH1), evening relative humidity (RH2), sunshine hours (SSH), wind speed (WS) and growing degree days (GDD) were recorded at the Agro-meteorological observatory of SDAU located in the Agronomy Instructional Farm and then converted into weekly basis against the standard meteorological week (SMW) with correspondence to weekly population of aphid. Gowning degree days (GDD) was calculated by considering base temperature as $5.0{ }^{0} \mathrm{C}$ following Chakravarty and Sastry (1983). The pooled data of aphid population over the years was taken for the correlation and regression analysis. The weekly population of aphid was considered as dependent variable and correlated with corresponding weekly weather parameters as independent variables. On the bases of significant correlation coefficients between aphid population and weather variables, stepwise regression study was performed to develop statistical forewarning models. Statistical Package for Social Science (SPSS) computer software version 20 was used for correlation and regression analysis. 


\section{Results and Discussion}

\section{Population dynamics of mustard aphid}

In timely sown crop (24-30 Sept), the appearance of aphid was started during $9^{\text {th }}$ week after sowing. While in late sown crop (15-21 Oct), it was appeared during $6^{\text {th }}$ week after sowing. However, the appearance of aphid was seen simultaneously in both sowing dates when weekly maximum and minimum temperatures were $31.0 \quad 0 \mathrm{C}$ and $13.50 \mathrm{C}$ respectively. Thereafter, the population of pest increased further with decreasing of temperature. The incidence increased rapidly from $14^{\text {th }}$ week after sowing in timely sown crop and peak population (256 aphids per shoot) was recorded in cultivar GSC-6 during $17^{\text {th }}$ week after sowing (Fig. 1). Thereafter, the population of aphid was found to decrease and remain active up to $23^{\text {rd }}$ week after sowing. Similarly, the incidence increased rapidly from $11^{\text {th }}$ week after sowing in late sown crop and peak population (455 aphids per shoot) was recorded in cultivar GDM-4 during $15^{\text {th }}$ week after sowing (Fig. 2). Thereafter, it was decreased gradually and disappeared during $23^{\text {rd }}$ week after sowing. The maximum activity of aphid was remained in between $15^{\text {th }}-20^{\text {th }}$ week after sowing $\left(1^{\text {st }}\right.$ $6^{\text {th }}$ SMW) in timely sown crop and $12^{\text {th }}-19^{\text {th }}$ week after sowing $\left(1^{\text {st }}-8^{\text {th }}\right.$ SMW $)$ in late sown crop respectively. It may be due to the prevailing maximum and minimum temperatures during peak activity of aphid found congenial for aphid multiplication.

Thus, in late sown crop, all cultivars infested relatively more as compared to timely sown crop. The incidence of aphid was found less in cultivar T-27 in both timely and late sown crop as compared to other cultivars.

The appearance of aphid started three week earlier in late sown crop as compared to timely sown crop. Malik and Sachan (2013) also reported that incidence of mustard aphid started in the third week of December and reaching peak population in the second week of February. Basiva et al. (2018) observed that, the aphid population started right from flowering to maturity of crop and initial population was comparatively low but as the temperature decreased, the population multiplied very fast.

\section{Correlation between mustard aphid and weather parameters}

In order to find out the association between aphid population and different weather parameters correlation study was performed between weekly aphid population and corresponding weekly weather parameters. Since, the incidence of aphid was seen simultaneously in both sowing dates, the population of aphid was averaged with respective cultivars and used for correlation study. The correlation coefficients between aphid population and weather parameters presented in Table 1. The results revealed that, maximum temperature (Tmax) minimum temperature (Tmin) and growing degree days (GDD) had significant negative correlation with aphid population in all cultivars. Highest correlation coefficient was obtained with Tmax followed by GDD. Morning relative humidity (RH1), evening relative humidity (RH2), sunshine hours ( $\mathrm{SSH}$ ) and wind speed (WS) did not have significant correlation with aphid population. However, correlation coefficient was positive with RH1, RH2, and WS while it was negative with SSH.

Thus, the maximum and minimum temperatures found most influencing weather parameters in the present study.

As the maximum and minimum temperatures decreased, the multiplication of aphid population was found increased. Gami et al., (2002) observed significant negative correlation of aphid population with 
maximum and minimum temperature. Ahuja (1990) also observed negative association with maximum, minimum temperatures and sunshine hours with aphid population. Singh and Singh (1986) observed positive effect of the maximum and minimum temperature, morning relative humidity and evening relative humidity and sunshine hours on the population of mustard aphid.

\section{Forewarning models for mustard aphid}

The biological responses like insect populations are influenced not only by a single weather variable, but by the interaction effect of more than one variable. Hence, multiple regression models were developed based on significant correlation coefficients between aphid population and weather variables by using stepwise regression method for predicting aphid population.

Since, the aphid population highly significantly correlated with maximum temperature (Tmax) minimum temperature (Tmin) and growing degree days (GDD). Thus, the regression models were developed with Tmax and GDD. The developed models could explain 72 to 87 percent variation in aphid population in different cultivars (Table $2)$. These models are simple and easy in calculation and could be used to predict aphid population in mustard crop well in advance. Thus, based on the predictions from such models under changing scenarios of climate, pest population could be managed efficiently through ecological manageable practices like timely application of insecticides, adjustment of sowing time and selection of varieties etc. that would be helpful to obtained higher yield.

Table.1 Correlation coefficient between aphid population and weather parameter

\begin{tabular}{|l|c|c|c|c|c|}
\hline \multirow{2}{*}{$\begin{array}{l}\text { Weather } \\
\text { parameter }\end{array}$} & \multicolumn{5}{|c|}{ Cultivar } \\
\cline { 2 - 6 } & BSH-1 & GSC-6 & T-27 & GS-1 & GDM-4 \\
\hline Tmax & $-0.857 * *$ & $-0.896 * *$ & $-0.781 * *$ & $-0.896 * *$ & $-0.889 * *$ \\
\hline Tmin & $-0.665 * *$ & $-0.709 * *$ & $-0.579 *$ & $-0.732 * *$ & $-0.723 * *$ \\
\hline RH1 & 0.387 & 0.413 & 0.366 & 0.433 & 0.434 \\
\hline RH2 & 0.093 & 0.129 & 0.036 & 0.168 & 0.174 \\
\hline SSH & -0.371 & -0.340 & -0.395 & -0.352 & -0.418 \\
\hline WS & 0.235 & 0.254 & 0.240 & 0.240 & 0.195 \\
\hline GDD & $-0.667 * *$ & $-0.711 * *$ & $-0.581 * *$ & $-0.736 * *$ & $-0.726 * *$ \\
\hline
\end{tabular}

*Significant at $5 \%$ level **Significant at $1 \%$ level

Table.2 Forewarning models for mustard aphid for different cultivars

\begin{tabular}{|l|l|c|}
\hline Cultivar & Forewarning models & R squire \\
\hline BSH-1 & $Y=1800.821-73.895 \mathrm{Tmax}+4.070 \mathrm{GDD}$ & 0.82 \\
\hline GSC-6 & $\mathrm{Y}=2095.464-84.628 \mathrm{Tmax}+4.343 \mathrm{GDD}$ & 0.87 \\
\hline T-27 & $\mathrm{Y}=940.547-40.098 \mathrm{Tmax}+2.500 \mathrm{GDD}$ & 0.72 \\
\hline GS-1 & $\mathrm{Y}=1300.502-41.114 \mathrm{Tmax}$ & 0.80 \\
\hline GDM-4 & $\mathrm{Y}=1327.458-42.126 \mathrm{Tmax}$ & 0.79 \\
\hline
\end{tabular}


Fig.1 Population of mustard aphid in timely sown crop at Sardarkrushinagar

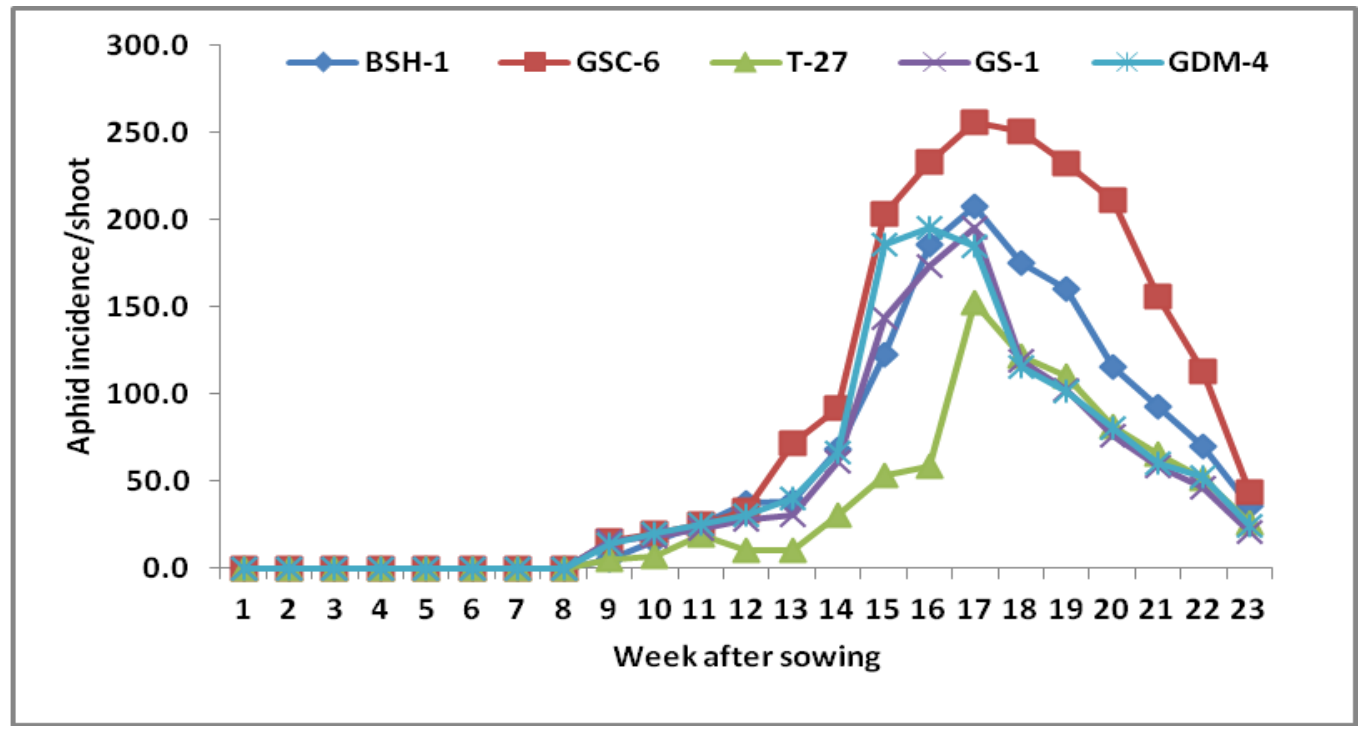

Fig.2 Population of mustard aphid in late sown crop at Sardarkrushinagar

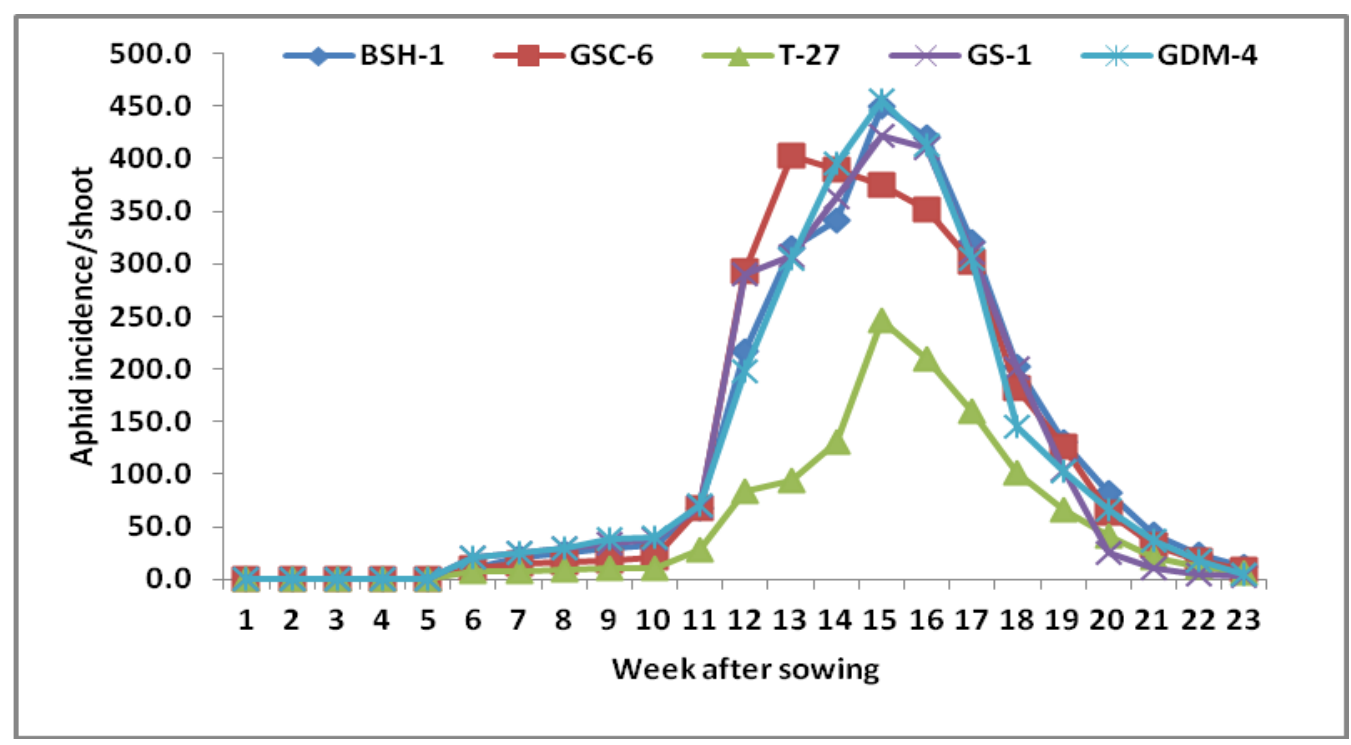

The results of present finding may be concluded that, incidence of mustard aphid was found vary with sowing dates. Late sown crop was suffered with much incidence of aphid as compared to timely sown crop. Weather parameters like Tmax, Tmin and GDD were found to significant influence on initiation and development of aphid in the present study. With decreased of temperature the multiplication of aphid was found increased. Thus, the developed models with Tmax and GDD caused $72-87 \%$ variation in aphid population and could be used to predict aphid incidence in mustard crop.

\section{References}

Ahuja, D.B. 1990. Population dynamics of mustard aphid Lipaphis erysimi (Kalt.) on Indian mustard, Brassica juncea 
(subsp. juncea). Indian J. Plant Prot. 18(8): 233-35.

Ali, A and P.Q. Rizvi, 2007. Development and predatory performance of Coccinella septempuncutata L. on different aphid species. J. Biol. Sci., 7: 1478-1483.

Bavisa, R., Parmar, G.M., Hirapara, M.M. and Acharya, M.F. 2018. Population dynamics of mustard aphid, Lipaphis erysimi (Kaltenbach) on mustard in relation to different weather parameters. Journal of Pharmacognosy and Phytochemistry 2018; 7(4): 394-396.

Chakravarty, N.V.K. and Sastry, P.S.N. 1983. Biomass production in wheat relation to evaporative demand and ambient temperature. Mausam 34(3): 323-327.

Gami, L.M., J.G. Bapodra, RR. Rathod. 2002. Population dynamics of mustard aphid Lipaphis erysimi (Kaltenbach) in relation to weather parameters. Indian Journal of Plant Protection 30: 20204.

Jitendra Kumar, Y.P. Malik and S.V. Singh. 1999. Forecasting models for outbreak of Lipaphis erysimi on some cultivars of mustard, Brassica juncea. Ind. $J$ Entomol. 61 (1): 59-64.

Malik R, Sachan SK. Population build up of mustard, Lipaphis erysimi (Kalt.) on indian mustard in relation to some abiotic factors. Progressive Agriculture. 2013; 13(1):153-157.

Prasad, S.K., K.G. Phadke, K.N. Mehrotra. 1984. Forecasting of mustard aphid,
Lipaphis erysimi (Kaltenbach) on rapeseed crop. Proc. Indian Nat. Sci. Acad. (B) 50:146-153.

Rana,J.S., Khokhar,K.S., Singh, H. and Suchetra 1993. Influence of abiotic environment on the population dynamics of mustard aphid Liphaphis erysimi (Kalt.) Crop Res. Hisar, 6(1): 116-119.

Roy, Pranab. 1975. Population dynamics of mustard aphid, Lipaphis erysimi (Kaltenbach) (Aphididae: Hemiptera) in West Bengal. Indian J. Ent. 37(3): 318-321.

Singh, H. and B. Singh. 1986. In: Proc. Nath. Conf. on key pests of agricultural crops, held at C.D.A. University of Agric. \& Tech., Kanpur, from 21-23 December, 1985, Pp. 117-123.

Srivatsava, A. 1999. Effect of date of sowing and varieties on the incidence of mustard aphid, Lipaphis erysimi (Kalt.) on rapeseed mustard. $J$. Oilseeds Res. 16(2): 380-381.

Srivatsava, A.S. and J. L. Srivatsava. 1972. Ecological studies on aphid, painted bug and saw fly attacking mustard and rape in India. F.A.O. Plant Prot. Bull. 20:136-140.

Vekaria, M.V. and G.M. Patel 2000. Screening of promising Brassica and allied genotypes for resistance against mustard aphid, Lipaphis erysimi Kalt. (Homoptera: Aphididae). Applied Biol. Res. 4 (1-2): 75-77.

\section{How to cite this article:}

Sevak Das, D.N. Tejani, J.C. Patel, A.G.Desai, A.I. Desai and Gangwar, G.P. 2019. Effect of Weather Parameters on Population Dynamics of Mustard Aphid. Int.J.Curr.Microbiol.App.Sci. 8(04): 1648-1653. doi: https://doi.org/10.20546/ijcmas.2019.804.192 